\title{
Association of Secondary Hyperparathyroidism with Hemoglobin Level in Patients with Chronic Kidney Disease
}

\section{Happy Chutia, Alice Abraham Ruram, Himashree Bhattacharyya ${ }^{1}$, Polina Boruah, Chandan Nath}

Departments of Biochemistry, ${ }^{1}$ Community Medicine, North East Indira Gandhi Institute of Health and Medical Science, Shillong, Meghalaya, India

Address for correspondence: Dr. Happy Chutia, E-mail: happy.chutia@gmail.com

\section{ABSTRACT}

Purpose: Secondary hyperparathyroidism (SHPT) is one of the less recognized reasons of anemia in chronic kidney disease (CKD). In this study, we evaluated the role of SHPT as a cause of anemia and correlation of intact parathyroid hormone (iPTH) and hemoglobin ( $\mathrm{Hb}$ ) level in hemodialysis (HD) patients.

Methods: This cross-sectional study was carried out in 63 individuals admitted in HD unit of the institute. Serum samples were collected and urea, creatinine, Hb, ferritin and iPTH levels were measured. Statistical analysis was carried out using the SPSS software (IBM, NY, USA).

Results: Mean \pm standard deviation for serum urea, creatinine, Hb, ferritin and intact PTH were $177 \pm 15.52$, $15.16 \pm 2.28 \mathrm{mg} / \mathrm{dl}, 7.03 \pm 2.26 \mathrm{~g} / \mathrm{dl}, 654.7 \pm 563.4 \mathrm{ng} / \mathrm{ml}, 539.18 \pm 493.59 \mathrm{pg} / \mathrm{ml}$ respectively. A reverse correlation was found between intact PTH and $\mathrm{Hb}$ level.

Conclusions: A variety of postulated pathophysiological mechanisms linking SHPT and anemia in CKD are discussed. An efficient control of parathyroid hormone hypersecretion may be required to achieve a better management of anemia in HD patients.

Key words: Anemia, chronic kidney disease, ferritin, hemoglobin, intact parathyroid hormone, secondary hyperparathyroidism

\section{INTRODUCTION}

hronic kidney disease (CKD) is defined as functional abnormalities of the kidney lasting longer than 3 months, with or without reduced glomerular filtration rate. It can also be defined by the presence of urinary albumin with an excretion rate higher than $300 \mathrm{mg} / 24 \mathrm{~h}$ or in a ratio of more than $200 \mathrm{mg}$ of albumin to $1 \mathrm{~g}$ of creatinine. ${ }^{[1]}$ The prevalence of $\mathrm{CKD}$, in India ranges from $0.79 \%$ to $1.4 \%{ }^{\left[{ }^{[2]}\right.}$

Hyperparathyroidism secondary to CKD is an overproduction of parathyroid hormone (PTH) caused

\begin{tabular}{|l|l|}
\hline \multicolumn{2}{|c|}{ Access this article online } \\
\hline Quick Response Code: & Website: \\
\hline & \\
\hline
\end{tabular}

by several changes that occur in bone and mineral metabolism as a result of decreased kidney function. The first change that usually occurs with declining kidney function involves the deficiency of activated vitamin $\mathrm{D}$ and an increase in phosphorus excretion by the remaining functional nephrons. Both of these changes stimulate an increase in PTH synthesis and secretion. Secondary hyperparathyroidism (SHPT) develops early in the course of the disease before dialysis initiation. Unfortunately, it is often unrecognized and inadequately treated in patients with early stages of kidney disease when therapy would have greater benefits.

Anemia has been recognized as a possible complication of primary hyperparathyroidism. ${ }^{[3]}$ Since hyperparathyroidism can induce anemia in patients with normal kidney function, SHPT due to CKD may also have an unfavorable influence on anemia of uremic patients. There is also indirect evidence of restoration of the hematocrit after parathyroidectomy in uremic patients due to restoration of bone 
marrow space after operation and rise of immunoreactive erythropoietin (EPO) serum concentrations. ${ }^{[4]}$

Factors that may be responsible for anemia in CKD are blood loss, shortened red cell life span, vitamin deficiencies, EPO deficiency, iron deficiency, infection and inflammation. Among these, EPO deficiency is considered as the most important cause. ${ }^{[5]}$ The introduction of recombinant human erythropoietin (rhEPO) therapy in the early 1990s for treatment of anemia of patients undergoing hemodialysis (HD) has led to a significant reduction in anemia and to an improvement in patients' quality-of-life. ${ }^{[5]}$ However, there is a significant variability among HD patients in the sensitivity to rhEPO. Moreover, around $5-10 \%$ of the patients show a marked resistance to rhEPO therapy. ${ }^{[6-10]}$ The European Best Practice Guidelines define "resistance to rhEPO therapy" as a failure to achieve target hemoglobin (Hb) levels (between 11 and $12 \mathrm{~g} / \mathrm{dl}$ ) with maintained doses of rhEPO. ${ }^{[6]}$ There are many causes of this variability of resistance to rhEPO therapy. One of the possible reasons may be SHPT. Hemodialysis patients with SHPT, usually associated with osteitis fibrosa on bone histology, show considerable resistance to EPO, which is partly because of replacement of the bone marrow by fibrous tissue.

In this study, we have analyzed the effect of SHPT in aggravating the anemia and correlation of intact parathyroid hormone (iPTH) and $\mathrm{Hb}$ level if there is any, in $\mathrm{HD}$ patients.

\section{MATERIALS AND METHODS}

This cross-sectional study was carried out in 63 patients admitted in HD unit of North East Indira Gandhi Institute of Health and Medical Science. Serum urea, creatinine, Hb, ferritin and intact PTH were measured. Patients taking angiotensin-converting enzyme-inhibitors, non-steroidal anti-inflammatory drugs and those having external blood loss were excluded. Baseline data of patients like age and sex were recorded. Institutional review was not necessary as it was a retrospective study.

All blood specimens were drawn as pre-dialysis. Blood chemistry analysis was carried out with the Beckman coulter auto-analyzer AU2700. Serum ferritin and intact PTH were assayed by chemiluminescence method (Access2, Beckman coulter).

A database was constructed on Microsoft Excel 2007 and statistical analyses were performed using the SPSS software version 20.0 (IBM, NY, USA).

\section{RESULTS}

In our study, comprising 63 patients $31(49.2 \%)$ were men and $32(50.8 \%)$ were women with nearly equal sex distribution. 17 patients $(27.0 \%)$ were in the age group 20-40 years, $33(52.4 \%)$ were in the age group 40-60 years and $13(20.6 \%)$ were in the age group $60-80$ years. Mean \pm standard deviation for serum urea, creatinine, $\mathrm{Hb}$, ferritin and $\mathrm{PPTH}$ were $177 \pm 15.52 \mathrm{mg} / \mathrm{dl}, 15.16 \pm 2.28 \mathrm{mg} / \mathrm{dl}, 7.03 \pm 2.26 \mathrm{~g} / \mathrm{dl}$ $654.7 \pm 563.4 \mathrm{ng} / \mathrm{ml}, 539.18 \pm 493.59 \mathrm{pg} / \mathrm{ml}$ respectively.

Three patients (4.8\%) had normal iPTH levels $(12-88 \mathrm{pg} / \mathrm{ml})$ and rest of patients had raised levels of iPTH (95.2\%). With respect to ferritin, $23(36.5 \%)$ had normal ferritin level of $11-336 \mathrm{ng} / \mathrm{ml} ; 40(63.5 \%)$ had a raised levels of ferritin. All patients had $\mathrm{Hb}$ level of $<13 \mathrm{~g} / \mathrm{dl}$.

No significant association was observed between age and $\mathrm{iPTH}$ (Chi-square $=6.967, \mathrm{df}=4$ ), age and $\mathrm{Hb}$ levels (Chi-square $=2.027, \mathrm{df}=6, P>0.05$ ) and between age and ferritin levels. (Chi-square $=8.361$, $\mathrm{df}=4, P>0.05)$. Furthermore, no significant association was observed between ferritin and iPTH levels. (Chi-square $=4.550$, df $=4, P>0.05$ ) and ferritin and $\mathrm{Hb}$ levels (Chi-square $=4.766$, $\mathrm{df}=6, P>0.05$ ). A significant association was however observed between PTH and Hb levels (Chi-square $=26.942$, $\mathrm{df}=6$, $P<0.001)$.

Similarly, bivariate analysis was carried out including serum PTH, Hb, Age and ferritin did not show any relationship between these parameters except $\mathrm{Hb}$ and PTH i.e., a Pearson's correlation of -0.545 and covariance -0.609 .3 , which were statistically significant.

A reverse correlation was found between intact PTH and $\mathrm{Hb}$ level $(r=-0.545)$, which indicates that the variables iPTH and $\mathrm{Hb}$ level are inversely proportional to each other [Figure 1]. More importantly, no correlation was observed between iPTH and ferritin $(r=0.0709)$ indicating that anemia is not due to depleted iron stores.

\section{DISCUSSION}

The development of SHPT as well as anemia is a common complication of CKD. The World Health Organization has defined anemia as an $\mathrm{Hb}$ concentration lower than $13.0 \mathrm{~g} / \mathrm{dl}$ in men and post-menopausal women and less than $12.0 \mathrm{~g} / \mathrm{dl}$ in other women. In this study, a significant association was found between PTH and $\mathrm{Hb}$ level, which is consistent with the findings of Baradaran and Nasri, ${ }^{[11]}$ Sliem et al. ${ }^{[12]}$ and Trovato et al. ${ }^{[13]}$ A reverse correlation 


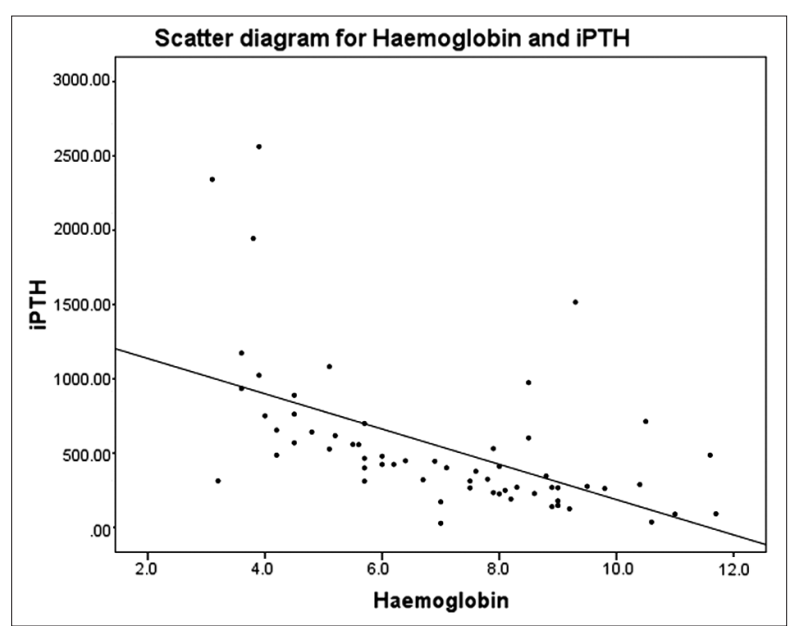

Figure 1: Scatter diagram showing reverse correlation between iPTH and $\mathrm{Hb}$ level in CKD patients

was found between PTH and Hb level. Possible causes of low $\mathrm{Hb}$ level or anemia due to SHPT may be because of increased bone marrow fibrosis, which may lead to decreased erythropoietin and increased resistance to EPO ${ }^{[14]}$ Erythropoietin cells express calcitriol receptors, which induces proliferation and maturation of erythroid progenitor cells. Therefore, deficiency of calcitriol, a cause of hyperparathyroidism may impair erythropoiesis. There are also some studies, which support an increase in erythrocyte osmotic fragility due to high concentration of PTH in patients on dialysis, leading to low Hb level. ${ }^{[15]}$

Management of SHPT is a challenge frequently encountered in the patients with CKD. Down-regulation of the parathyroid vitamin $\mathrm{D}$ and calcium-sensing receptors are the critical steps that lead to abnormalities in mineral metabolism: High phosphate, low calcium and vitamin $\mathrm{D}$ deficiency. These imbalances result in parathyroid hyperplasia leading to SHPT and elevated serum calcium, phosphorus, calcium-phosphorus product. As a result of these, relative risk of mortality increases. ${ }^{[16]}$

An efficient control of PTH hypersecretion is therefore required to achieve a better management of anemia as well as mineral metabolism in HD patients.

The medical management of SHPT in patients with CKD principally involves dietary changes, the use of the combination of phosphate binders, active vitamin $\mathrm{D}$ analogs and/or calcimimetics (which increase the sensitivity of the calcium sensing receptors to calcium) ${ }^{[16]}$ In addition, they need treatment of underlying conditions including hypertension, cardiac ailments and diabetes.

Patients with CKD need special diet with restriction of salt, potassium, phosphorous and other electrolytes.
Protein restriction while getting enough calories to prevent weight loss is also needed. However, dietary recommendations may change over time as patient's disease progresses. For example, during dialysis protein requirement increases hence patient needs extra proteins. Calcium supplementation is necessary to prevent loss of calcium from bones; however, dairy products must be avoided they also contain high amount of phosphorus. Restricting fluids, common salt and fruits containing high potassium is also needed to maintain adequate fluid and electrolyte balance. Patient also needs extra iron to prevent anemia, which can occur because of various reasons already mentioned. ${ }^{[17-20]}$

More wider and detailed studies are necessary to confirm the findings and to explain the mechanisms underlying the improvement in anemia after medical or surgical treatment of SHPT.

\section{ACKNOWLEDGMENTS}

We are thankful to the patients for their participation and to the team of biochemistry and pathology laboratories for their help. We are also thankful to the hemodialysis unit of the institute for their support. Dr. Akash Handique provided us helpful feedback on the manuscript.

\section{REFERENCES}

1. National Kidney Foundation. K/DOQI clinical practice guidelines for chronic kidney disease: Evaluation, classification, and stratification. Am J Kidney Dis 2002;39(Suppl 1):S1-266.

2. Rajapurkar M, Dabhi M. Burden of disease-Prevalence and incidence of renal disease in India. Clin Nephrol 2010;74 (Suppl 1):S9-12.

3. Zingraff J, Drüeke T, Marie P, Man NK, Jungers P, Bordier P. Anemia and secondary hyperparathyroidism. Arch Intern Med 1978;138:1650-2.

4. Joy MS, Karagiannis PC, Peyerl FW. Outcomes of secondary hyperparathyroidism in chronic kidney disease and the direct costs of treatment. J Manag Care Pharm 2007;13:397-411.

5. Nurko S. Anemia in chronic kidney disease: Causes, diagnosis, treatment. Cleve Clin J Med 2006;73:289-97.

6. Costa E, Belo L, Quintanilha A, Santos-Silva A. Resistance to recombinant human erythropoietin therapy in hemodialysis patients- Focus on inflammatory cytokines, leukocyte activation, iron status and erythrocyte damage. J Nephrol Ren Transplant 2009;2:66-83.

7. Bárány P. Inflammation, serum C-reactive protein, and erythropoietin resistance. Nephrol Dial Transplant 2001;16:224-7.

8. Smrzova J, Balla J, Bárány P. Inflammation and resistance to erythropoiesis-stimulating agents - What do we know and what needs to be clarified? Nephrol Dial Transplant 2005;20(Suppl 8):viii,2-7.

9. Macdougall IC, Cooper AC. Erythropoietin resistance: The role of inflammation and pro-inflammatory cytokines. Nephrol Dial Transplant 2002;17(Suppl 11):39-43.

10. Schindler R, Senf R, Frei U. Influencing the inflammatory response of haemodialysis patients by cytokine elimination using large-pore membranes. Nephrol Dial Transplant 2002;17:17-9.

11. Baradaran A, Nasri H. Intensification of anaemia by secondary 
hyperparathyroidism in hemodialysis patients. Med J Islam Acad Sci 2001;14:4,161-6.

12. Sliem H, Tawfik G, Moustafa F, Zaki H. Relationship of associated secondary hyperparathyroidism to serum fibroblast growth factor-23 in end stage renal disease: A case-control study. Indian J Endocrinol Metab 2011;15:105-9.

13. Trovato GM, Carpinteri G, Spina S, Squatrito G, Catalano D, Iannetti E. Hyperparathyroidism, anaemia and erythropoietin: Effects on systolic function of dialysis patients. Abstracts of $31^{\text {st }}$ Congress of European Renal Association/European dialysis ND Transplantation Association, September 5-8, 1999, Madrid in Nephrol Dial Transpl 1999;14:190.

14. Gallieni M, Corsi C, Brancaccio D. Hyperparathyroidism and anemia in renal failure. Am J Nephrol 2000;20:89-96.

15. Wu SG, Jeng FR, Wei SY, Su CZ, Chung TC, Chang WJ, et al. Red blood cell osmotic fragility in chronically hemodialyzed patients. Nephron 1998;78:28-32.

16. Cunningham J, Locatelli F, Rodriguez M. Secondary hyperparathyroidism: Pathogenesis, disease progression, and therapeutic options. Clin J Am Soc Nephrol 2011;6:913-21.

17. Abboud H, Henrich WL. Clinical practice. Stage IV chronic kidney disease.
N Engl J Med 2010;362:56-65.

18. Dietary Guidelines for Adults Starting on Hemodialysis, 2010. National Kidney Foundation. Available from: http://www.kidney.org/atoz/pdf/ nutri_hemo.pdf [Last accessed on 2013 May 31].

19. Kidney Failure Eat Right To Feel Right On Hemodialysis. NIH Publication. National Institute of Diabetes and Digestive and Kidney Diseases (NIDDK. Weblink: Available from: http://kidney.niddk.nih.gov/kudiseases/pubs/ eatright/ [Last accessed on 2013 May 31].

20. Anaemia Management in Chronic Kidney Disease. Rapid Update 2011. NICE Clinical Guidelines, No. 114 National Clinical Guideline Centre (UK). London: Royal College of Physicians (UK); 2011. weblink: Available from: http://www. ncbi.nlm.nih.gov/books/NBK65527/ [Last accessed on 2013 May 31].

How to cite this article: Chutia $H$, Ruram AA, Bhattacharyya $H$, Boruah $\mathrm{P}$, Nath $\mathrm{C}$. Association of secondary hyperparathyroidism with hemoglobin level in patients with chronic kidney disease. J Lab Physicians 2013;5:51-4.

Source of Support: Nil. Conflict of Interest: None declared.

Announcement

\section{Android App}

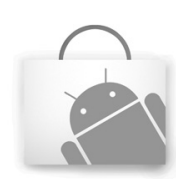

A free application to browse and search the journal's content is now available for Android based mobiles and devices. The application provides "Table of Contents" of the latest issues, which are stored on the device for future offline browsing. Internet connection is required to access the back issues and search facility. The application is compatible with all the versions of Android. The application can be downloaded from https://market.android.com/details?id=comm.app.medknow. For suggestions and comments do write back to us. 